\title{
Teachers' readiness to work with children with signs of psychomotor aptitude
}

\author{
Marina Mikhailovna Borisova ${ }^{1 *}$, Nadezhda Petrovna Pavlova ${ }^{1}$, Svetlana Evgenievna \\ Shukshina ${ }^{1}$, and Ludmila Dmitrievna Morozova ${ }^{1}$ \\ ${ }^{1}$ Moscow City Pedagogical University, Institute of Pedagogy and Psychology of Education, \\ Department of Pedagogy, Moscow, Russia
}

\begin{abstract}
The paper deals with the problem of teachers' readiness to work with children showing signs of psychomotor aptitude. The authors perform a theoretical analysis of approaches to the definition of the concepts of psychomotor, psychomotor aptitude, physical intelligence. The place of psychomotor aptitude in the structure of general aptitude has been determined. The relationship between psychomotor skills and personality development is demonstrated. It was found that most of the children with signs of psychomotor aptitude remained without proper psychological and pedagogical support, which led to a significant decrease in their number with age. The main goal of the study is to determine the readiness of teachers to work with psychomotorically apt children. A diagnostic technique has been developed, aimed at determining the readiness of teachers to work with the specified contingent of children. The main attention was paid to the formation of the cognitive and activity components of readiness among teachers. The study was based on a comparative analysis of data obtained in two groups of respondents with different levels of professional training. Approaches to the definition of the concepts of readiness and professional readiness are generalized. The content of professional competencies (such as "knowing", "being able") in the context of the problem under consideration is presented. The results of the empirical study showed that in the process of professional training, the concept of psychomotor aptitude had not been formed. The ideas of the experiment participants about scientific and methodological approaches to organizing work with psychomotorically apt children are at an intuitive level, which indicates that teachers are not ready for this type of work and cannot fully take into account the special educational needs of their students. The prospects for further research in the field of training teachers to work with children with psychomotor aptitude have been determined.
\end{abstract}

Keywords: aptitude, psychomotor skills, professional competence.

\footnotetext{
*Corresponding author: marinagrisha2005@mail.ru
} 


\section{Introduction}

In the practice of preschool and primary education, the problem of working with children with special educational needs, in particular, those who have signs of special aptitude, has acquired relevance. From the general population of children from $1-2 \%$ to $20 \%$ have signs of being apt in a particular sphere. The statistical difference in assessing the number of apt children in the world ranges from 7 to $90 \%$ and is due to diagnostic methods. In Russia, according to various sources, there are about $7 \%$ of apt and up to $30 \%$ of potentially apt children [1], or $1 \%$ of talented, $20 \%$ of clearly apt, $20 \%$ of potentially apt children [2].

The results of the analysis show that most researchers study the intellectual and creative aptitude of children, while other types of aptitude are left without due consideration. When identifying the types of aptitude, the researchers of this problem [3-9] singled out psychomotor aptitude, which is based on the concept of psychomotorics defined as special human movements that allow control and self-regulation of mental processes.

There are several groups of qualities that characterize psychomotor skills, such as coordination abilities, proprioceptive functions, memory for the main parameters of movements, performance indicators, muscle strength, joint mobility, speed-strength qualities, endurance, accuracy, and dexterity.

Psychomotor skills are considered in the context of the problem of personality development and the person's needs in various types of activity [10-12].

The development of the concepts of psychomotor aptitude continues and the most interesting is its consideration from the standpoint of physical intelligence [13-25].

There are very little data on children with signs of psychomotor aptitude. However, they allow us to conclude that out of the total number of such children, only less than $30 \%$ receive pedagogical support. The rest of the motorically apt children are left without special methodological, psychological, and pedagogical support (which leads to a loss of interest in certain types of activity and natural prerequisites and inclinations) [26].

According to statistics, with age, the percentage of apt children decreases by 3-4 times, which may have a direct causal relationship with the teachers' unreadiness to work with such children. Based on this, the following problem of the study was determined: are teachers ready to work with children who have signs of psychomotor aptitude?

Purpose of the study: To determine the theoretical and practical readiness of teachers to work with children with signs of psychomotor aptitude.

Objectives:

- To clarify the scientific concept "teacher's readiness to work with children with signs of psychomotor aptitude."

- To reveal the ideas of teachers about psychomotor aptitude.

- Determine the relationship between the level of professional training and the readiness of teachers to work with children with psychomotor aptitude.

Hypothesis: we believe that teachers do not have sufficiently formed professional competencies to provide psychological and pedagogical support for children with signs of psychomotor aptitude.

\section{Methods}

A theoretical analysis of psychological and pedagogical literature, questionnaires, mathematical processing of empirical data, a comparative analysis was carried out.

The study of the teachers' readiness (concerning the cognitive and activity components) to work with children with signs of psychomotor aptitude was participated in by bachelor and master program students studying at the Institute of Pedagogy and Psychology of Education of the Moscow City Pedagogical University and the Pedagogical Institute of Tambov State 
University named after G.R. Derzhavin in the Pedagogical Education, Psychological and Pedagogical Education program, as well as practicing teachers. The study population consisted of 198 people. The participants were divided into two groups: group A included undergraduate students (82) and group B included graduates and practicing teachers (116).

A questionnaire was developed, aimed at identifying knowledge about general aptitude, its types; psychomotor aptitude, its signs, ways of formation in children. It was also clarified whether the students had any professional training for working with children with signs of psychomotor aptitude in the process of their studies.

\section{Results}

Formation of the teacher's readiness to work with apt children is one of the requirements of modern education. Summarizing the approaches to the definition of the concepts of readiness and professional readiness [27-40], we identified the most common characteristics, namely a sufficient level of knowledge, skills, experience; subjective assessment of the individual's abilities and readiness to perform professional activities.

The teacher's readiness is based on mastering general professional competencies, the necessary knowledge, and skills, work-related actions aimed at organizing the educational process, and psychological and pedagogical support of children with special educational needs (which include children with psychomotor aptitude), which should be formed in the process of professional training.

We formulated the characteristic of the teacher's readiness to work with children with signs of psychomotor aptitude: such teacher knows the basics of higher nervous activity, the anatomical and physiological characteristics of children and the theory of building movements, the components of psychomotor aptitude, psychological and pedagogical technologies necessary for working with such children; knows the methods of diagnosing psychomotor aptitude and predicting the prospects for its development based on the monitoring results; can design personality-oriented development programs and individual educational routes; knows effective methods of work and techniques for training children.

The results of the study of the formed competencies (cognitive and activity components) in the field of psychomotor aptitude of children among the respondents of both groups are presented in Table 1.

Table 1. Comparative survey results

\begin{tabular}{|l|l|c|c|}
\hline $\begin{array}{c}\text { Questions included in } \\
\text { the questionnaire }\end{array}$ & \multicolumn{1}{|c|}{$\begin{array}{c}\text { Participants' most common } \\
\text { responses }\end{array}$} & $\begin{array}{c}\text { Group A } \\
\text { responses, \% }\end{array}$ & $\begin{array}{c}\text { Group B } \\
\text { responses, \% }\end{array}$ \\
\hline 1. What is aptitude? & $\begin{array}{l}\text { high (potentially high) human } \\
\text { abilities for something (any kind of } \\
\text { activity) }\end{array}$ & $58.5 \%$ & $75.9 \%$ \\
\cline { 2 - 4 } & $\begin{array}{l}\text { a special gift, talent, features that are } \\
\text { inherent in a person from the } \\
\text { moment of birth }\end{array}$ & $23.2 \%$ & $15.5 \%$ \\
\cline { 2 - 4 } & $\begin{array}{l}\text { the relationship between aptitude } \\
\text { and intellectual development }\end{array}$ & $11.00 \%$ & $4.3 \%$ \\
\hline $\begin{array}{l}\text { 2. What types of } \\
\text { aptitude do you know? }\end{array}$ & intellectual aptitude & $42.7 \%$ & $58.6 \%$ \\
\cline { 2 - 4 } & creative aptitude & $23.2 \%$ & $84.5 \%$ \\
\cline { 2 - 4 } & motor aptitude & $11.0 \%$ & $30.2 \%$ \\
\cline { 2 - 4 } & psychomotor aptitude & $7.3 \%$ & $12.9 \%$ \\
\cline { 2 - 4 } & social aptitude & $63 \%$ & $3.3 \%$ \\
\cline { 2 - 4 } & couldn't say & $33.6 \%$ \\
\hline \multirow{2}{*}{$\begin{array}{l}\text { What } \\
\text { psychomotorics? }\end{array}$} & $\begin{array}{l}\text { a set of consciously controlled motor } \\
\text { actions }\end{array}$ & $6.3 \%$ & \\
\hline
\end{tabular}




\begin{tabular}{|c|c|c|c|}
\hline & $\begin{array}{l}\text { the relationship between motor and } \\
\text { mental development }\end{array}$ & $12.2 \%$ & $38.8 \%$ \\
\hline & involuntary body movements & - & $12,1 \%$ \\
\hline & couldn't say & $15.9 \%$ & $15.5 \%$ \\
\hline \multirow{3}{*}{$\begin{array}{l}\text { 4. What qualities are } \\
\text { relevant to psychomotor } \\
\text { skills? }\end{array}$} & physical qualities & $47.6 \%$ & $48.3 \%$ \\
\hline & $\begin{array}{l}\text { qualities that are not related to } \\
\text { psychomotor skills }\end{array}$ & $14.6 \%$ & $20.7 \%$ \\
\hline & couldn't say & $37.8 \%$ & $31 \%$ \\
\hline \multirow{3}{*}{$\begin{array}{l}5 . \text { How do you } \\
\text { understand the concept } \\
\text { of psychomotor } \\
\text { aptitude? }\end{array}$} & $\begin{array}{l}\text { ability to perform precise and fast } \\
\text { coordination movements and their } \\
\text { combinations }\end{array}$ & $22.0 \%$ & $49.1 \%$ \\
\hline & athletic aptitude & $7.3 \%$ & $12.9 \%$ \\
\hline & couldn't say & $24.4 \%$ & $11.2 \%$ \\
\hline \multirow{5}{*}{$\begin{array}{l}\text { 6. How are the } \\
\text { psychomotor abilities } \\
\text { expressed? }\end{array}$} & $\begin{array}{l}\text { in accurate and fast execution of } \\
\text { actions, movements/ in motor skills }\end{array}$ & $31.7 \%$ & $50.0 \%$ \\
\hline & in sports & $8.5 \%$ & $28.4 \%$ \\
\hline & in creative work & $22.0 \%$ & $9.5 \%$ \\
\hline & in educational activities & - & $7.8 \%$ \\
\hline & couldn't say & $40.2 \%$ & $25.0 \%$ \\
\hline \multirow{3}{*}{$\begin{array}{l}7 . \text { Is it possible to } \\
\text { develop psychomotor } \\
\text { aptitude? }\end{array}$} & yes & $41.5 \%$ & $45.7 \%$ \\
\hline & no & $4.9 \%$ & $10.3 \%$ \\
\hline & couldn't say & $53.7 \%$ & $44.0 \%$ \\
\hline \multirow{2}{*}{$\begin{array}{l}\text { 8. Did you learn the } \\
\text { concept of psychomotor } \\
\text { aptitude/ability in the } \\
\text { process of studying at } \\
\text { the university? }\end{array}$} & yes & $8.5 \%$ & $20.7 \%$ \\
\hline & no & $91.5 \%$ & $79.3 \%$ \\
\hline
\end{tabular}

\section{Discussion}

No statistically significant differences were found between the two groups in the definition of aptitude and the identification of its types. Most of the respondents draw attention to the potentially high abilities of a person for any kind of activity as a key characteristic of aptitude. Among the types of aptitude, the most often distinguished types are

intellectual, creative, and motor aptitude. Psychomotor aptitude is often viewed within the framework of motor aptitude, and only a small percentage of respondents in both groups distinguish it as a special type.

These results were reflected in the comprehension of the essence of this concept, which was formed by almost half of the respondents in group B and about $1 / 5$ of group A. At the same time, we noticed a part of the respondents who understood this type of aptitude in the narrow sense (as athletic aptitude).

Defining psychomotorics, the study participants established a connection between motor and mental development, and also concentrated on identifying a set of consciously controlled motor actions.

Answering the question about the essential characteristics of psychomotor skills, the participants in group A showed better results than in group B. The correct answer was found in that group twice more often. This may be since undergraduate students used the resources of the global search network without realizing the essence of the meaning of this concept. This conclusion may be due to the results of answers to question no. 6 of the questionnaire, where more than $1 / 3$ of the respondents in group A $(40,2 \%)$ found it difficult to identify the types of activities in which psychomotor abilities were manifested (in group B only $25 \%$ of respondents showed that result). 
The identification of qualities related to psychomotor skills caused difficulties for the respondents of both groups. Only slightly less than half of them correctly identified physical qualities (endurance, speed, strength, coordination, agility, accuracy), and the rest gave answers that were far from the essence of psychomotor skills or did not answer this question at all.

An analysis of the answers received allows us to conclude that the respondents have no idea about didactic (methodological, technological) approaches to the implementation of working with children who have signs of psychomotor aptitude. Intuitively, the respondents pointed to the need for purposeful work on the development of movements, physical qualities in the process of practicing special exercises, games, and organization of training.

The concept of psychomotor aptitude/ability in the process of professional training had not been formed among teachers. Only $1 / 5$ of the respondents in group B and 1/12 of the respondents in group A answered the corresponding question in the affirmative. If this type of aptitude was considered, it was mainly within the framework of (general, child, age, pedagogical, special) psychology, pedagogy, and physical training.

\section{Conclusion}

We have developed the characteristics of the teacher's readiness for work with children with signs of psychomotor aptitude based on cognitive and activity components, which allow reflecting the specifics of this type of activity.

A comparative analysis of the results obtained showed that there were no statistically significant differences in perceptions between the two groups of participants in the experiment. The teachers have not fully formed professional competencies in the psychological and pedagogical support of children with signs of psychomotor aptitude. Thus, it is possible to trace the relationship between the unpreparedness of teachers to work with such children and the lack of attention to the development of this type of aptitude in preschoolers and primary school students in practice.

In the structure of curricula, the content of educational programs, no attention is paid to issues related to the psychomotor aptitude of children and the technologies of its development.

As a prospect for further research, we see the development of modern methodological approaches to working with children with psychomotor aptitude; in clarifying the place and meaning of physical intelligence in the context of personal development; in adjusting the content of training modules and disciplines by expanding the theoretical and practiceoriented components of training future teachers.

\section{References}

1. N.Y. Sinyagina, Odarennyi Rebenok, 4, 26-36 (2005)

2. A.E.Karpov, D.A. Edelev, N.V. Maiorova, V.M. Fersht, Territoriya Novykh Vozmozhnostei. Vestnik VGUES, 1, 165-194 (2018)

3. E. P. Ilin, Psikhologiya tvorchestva, kreativnosti, odarennosti [Psychology of creativity, creativity, aptitude] (Piter, Moscow, 2012)

4. N.S. Leites, Prikladnaya Psikhologiya i Psikhoanaliz, 4, 60-74 (2002)

5. A.I. Savenkov, Psikhologiya detskoi odarennosti [The psychology of aptitude in children] (Yurait, Moscow, 2020)

6. V.D. Shadrikov, Sposobnosti i odarennost cheloveka [Human talents and aptitude] (Institut psikhologii RAN, Moscow, 2019) 
7. P.F. Lesgaft, Pedagogika. Izbrannye trudy [Pedagogy. Selected works] (Yurait, Moscow, 2017)

8. I.M. Sechenov, Fiziologiya. Izbrannye proizvedeniya. Chast 1 [Physiology. Selected works. Part 1] (Yurait, Moscow, 2019)

9. B.M. Teplov, Psikhologiya i psikhofiziologiya individualnykh razlichii [Psychology and psychophysiology of individual differences] (Izdatelstvo MPSI, Moscow, 2004)

10. N.A. Bernshtein, Biomekhanika i fiziologiya dvizhenii [Biomechanics and physiology of movement] (Izdatelstvovo Instituta Prakticheskoy Psikhologii, Moscow, 1997)

11. V.P. Ozerov, Psikhomotornye sposobnosti cheloveka [Psychomotor abilities of an individual] (Feniks+, Dubna, 2002)

12. V.N. Shebeko, Instruktor po Fizkulture, 2, 19-25 (2012)

13. V. V. Klimenko, Psikhomotornye sposobnosti yunogo sportsmena [Psychomotor abilities of a young athlete] (Zdorove, Kiev, 1987)

14. F. Galton, Nasledstvennost talanta: Zakony i posledstviya [Hereditary Genius, its Laws and Conseguences] (Mysl, Moscow, 1996)

15. G. Doman, Garmonichnoe razvitie rebenka: kak razvivat umstvennye i fizicheskie sposobnosti rebenka [Harmonious development of the child: how to develop the mental and physical abilities of the child] (Akvarium, Moscow, 1996)

16. N.I. Dvorkina, Sistema formirovaniya bazovoi lichnostnoi fizicheskoi kultury doshkolnikov. Nauchnaya monografiya [The system of formation of the basic personal physical culture of preschoolers. A scientific monograph] (Nauchno-izdatelskii tsentr Teoriya i praktika fizicheskoi kultury i sporta, Moscow, 2015)

17. J.A. Reed, G. Einstein, E. Hahn, S.P. Hooker, V.P. Gross, J. Kravitz, Journal of Physical Activity and Health, 7(3), 343-351 (2010). https://doi.org/10.1123/jpah.7.3.343 10.1123/jpah.7.3.343

18. F. O'Callaghan, M.O'Callaghan, G. Williams, W. Bor, J. Najman, Journal of Physical Activity and Health, 9(2), 218-224 (2012). https://doi.org/10.1123/jpah.9.2.218

19. J.J. Ratey, E. Hagerman, Spark: The Revolutionary New Science of Exercise and the Brain (Little, Brown and Company, New York, 2013)

20. V.A. Petkov, N.I. Roslyakova, V.M.Grebennikova, Vospitanie i Obuchenie Detei Mladshego Vozrasta [Education and Training of Young Children], 5, 830-832 (2016)

21. T. Lobel, Sensation: the new science of physical intelligence (Simon and Schuster, New York, 2020)

22. J.E. Donnelly, C.H. Hillman, D. Castelli, J.L. Etnier, S.Lee, P.Tomporowski, K.Lambourne, A.N. Szabo-Reed, Med Sci Sports Exerc., 48(6), 1223-1224 (2016). https://doi.org/10.1249/MSS.0000000000000901.

23. E. Yetti, H. Muanivah, Improved Intelligence Kinesthetic Children Ages 5-6 Years through Activities of Motion and Song, In the Proceedings of the International Conference Academic Community Empowerment Through International Journal Publication, January 13-14, 2017, Jakarta, Indonesia (2017)

24. O.M. Abdelkarim, International Sports Science Alexandria Journal, 2(1), 1-10 (2019). https://doi.org/10.21608/ISALEXU.2019.88852

25. F.J. Gil-Espinosa, P. Chillón, J.C. Fernández-García, C. Cadenas-Sanchez, International Journal of Environmental Research and Public Health, 17(12), 4362 (2020). https://doi.org/10.3390/ijerph17124362 
26. Ya. Kolominskii, E. Panko, V. Shebeko, A. Belous, Belorusskii gosudarstvennyi pedagogicheskii universitet im. M. Tanka. Praleska [Belarusian State Pedagogical University named after M. Tanka. Praleska], 2, 7-13 (2012)

27. E.A. Klimov, Psikhologiya professionalnogo samoopredeleniya [Psychology of professional self-determination] (Izdatelskii tsentr Akademiya, Moscow, 2010)

28. V.A.Slastenin, L.S. Podymova, Sibirskii Pedagogicheskii Zhurnal. Izdatelstvo: Novosibirskii Gosudarstvennyi Pedagogicheskii Universitet (Novosibirsk) [Siberian Pedagogical Journal. Publisher: Novosibirsk State Pedagogical University (Novosibirsk)], 1, 42-49 (2007)

29. S.N. Chistyakova, Professionalnoe Obrazovanie. Stolitsa [Professional Education. Capital], 4, 14-18 (2013)

30. R. Coe, C. Aloisi, S. Higgins, L. Elliot, Major What makes great teaching? Review of the underpinning research (Sutton Trust, London, 2014). Accessed on: February 17, 2021. [Online]. Available: http://www.suttontrust.com/wpcontent/uploads/2014/10/What-Makes-Great-Teaching-REPORT.pdf

31. L. Darling-Hammond, Creating a Comprehensive System for Evaluating and Supporting Effective Teaching (Stanford Center for Opportunity Policy in Education, Stanford, CA, 2012)

32. P. Hallinger, R.H. Heck, J. Murphy, Educ Asse Eval Acc, 26, 5-28 (2014). https://doi.org/10.1007/s11092-013-9179-5

33. S.G. Huber, G. Skedsmo, Educ Asse Eval Acc, 28, 105-109(2016). https://doi.org/10.1007/s11092-016-9241-1

34. M. Katsuno, Teacher Evaluation Policies and Practices in Japan: How performativity works in schools (1st ed.) (Routledge, London, 2016). https://doi.org/10.4324/9781315723013

35. D.S. Katz, Kappa Delta Pi Record, 52(1), 11-16 (2016). https://doi.org/10.1080/00228958.2016.1123039

36. K. Mihaly, D. F. McCaffrey, D. O. Staiger, J. R. Lockwood, A Composite Estimator of Effective Teaching (Bill \& Melinda Gates Foundation RAND Corporation, Seattle, WA, 2013)

37. G. W. Ritter, J. H. Barnett, Phi Delta Kappan, 97(7), 48-52 (2016)

38. M. F.C. Sanches, M. Jacinto, Procedia - Social and Behavioral Sciences, 116, 12011210 (2014). https://doi.org/10.1016/j.sbspro.2014.01.369

39. Y. Su, L. Feng, C. Hsu, Teachers and Teaching, 23(6), 717-728 (2017). https://doi.org/10.1080/13540602.2016.1255189

40. OECD, Teachers for the 21st Century: Using Evaluation to Improve Teaching (OECD Publishing, Paris, 2013). http://dx.doi.org/10.1787/9789264193864-en 